\title{
The socioeconomic impact of rural-origin graduates working as healthcare professionals in South Africa
}

\author{
Richard Gavin McGregor ${ }^{a}$ (D), Andrew John Ross ${ }^{b *}$ and Ganzamungu Zihindula ${ }^{a}$ \\ ${ }^{a}$ Umthombo Youth Development Foundation, Hillcrest, Durban, South Africa \\ ${ }^{b}$ College of Health Sciences Discipline of Family Medicine, University of KwaZulu-Natal, Durban, South Africa \\ *Corresponding author, email: rossa@ukzn.ac.za
}

Background: Studies documenting the socioeconomic impact of education leading to employment of rural youth, specifically in the healthcare professions, are lacking. The Umthombo Youth Development Foundation (UYDF) is an NGO that provides financial support for rural students to train as healthcare professionals (HCPs) as a way of addressing staff shortages at rural hospitals. The aim of this study was to understand the social and economic impact on individuals and their families of qualifying as an HCP and being employed at a rural district hospital

Methodology: A mixed methodology was used to collect data from 40 graduates at eight district hospitals in rural KwaZuluNatal province. The research tools had qualitative and quantitative questions, with additional data being extracted from the UYDF database. The qualitative data were analysed thematically, with STATA software being used for the quantitative analysis. Results: The findings indicate that graduate household assets increased significantly, as did their socioeconomic circumstances, compared with before they qualified as HCPs. Graduates attached high value to education that led to their employment, which provided them with money to afford assets. Having a permanent job and regular income also transformed their families' lives, as they were able to care for their siblings and extended family members.

Conclusions: Training rural youth for employment in scarce skills that leads to employment, such as a career in the health sciences, boosts their socioeconomic circumstances and that of their families. This contributes to the staffing of rural hospitals, job creation and the economic development of the country.

Keywords: education, HCPs, rural areas, socioeconomic impact, South Africa, UYDF, youth

\section{Background}

South Africa (SA) has the highest Gini coefficient in the world, indicating a large gap between the highest and lowest paid workers in the country. Recognising a need for economic and political transformation, the focus of the country's National Development Plan (NDP) was to create economic opportunities by investing in education and job creation. ${ }^{1}$ However, with an unemployment rate of $27 \%$, of which $52 \%$ are under the age of 30 years, ${ }^{2}$ new thinking is required to address the current challenges. The high unemployment rate has been linked to poor schooling, much of which is located in rural areas, which are generally characterised by low levels of income and a high dependency on social grants. ${ }^{3}$

A number of sub-Saharan African countries have invested in education and are seeing the social and economic impact of this decision. ${ }^{4,5}$ Studies from Nigeria affirm that education is often the first step toward the socioeconomic development of the people and country at large. ${ }^{6}$ Efanga and Oleforo (2012) have highlighted that sustainable development rarely takes place in the absence of skilled people who are able to bring economic change to the country. ${ }^{6}$ Other studies in low- and middle-income countries have identified a direct link between education, skilled people and overall national development. ${ }^{6,7}$ This economic growth is attributed to innovation, an increase in human capital ${ }^{8}$ and the increased earning capacity of those with post-school education. ${ }^{9}$

The Umthombo Youth Development Foundation (UYDF) is an NGO scholarship scheme that was initiated in 1999 with the purpose of staffing rural public health facilities by training rural origin students to become healthcare professionals (HCPs). ${ }^{10}$ Graduates are expected to return to the district hospital where they were selected to fulfil a year-for-year work-back obligation to the UYDF. This means that for every year of study paid for by the UYDF, they need to work a year in a rural health facility, with most degrees taking at least four years to complete. By the end of 2017, 337 rural-origin students had qualified as HCPs, with a further 253 rural-origin students supported by UYDF registered as full-time health sciences students at universities across SA in 2018. The focus of UYDF is to staff rural hospitals, and $98 \%$ of graduates have fulfilled their work-back obligation by working at a rural hospital. In addition, just under two-thirds of graduates supported by UYDF (63\%) continue to work in rural areas after completing their workback obligations, and continue to provide healthcare services to their communities. ${ }^{10}$ Both the number of graduates who honour their work-back obligations and the percentage of graduates who chose to work in rural areas after completion of this obligation are important indicators of the success of the UYDF scholarship scheme.

A 2016 economic analysis of UYDF data revealed that paying for the training of rural-origin HCPs is an investment (rather than an expense). While it cost R184 million to train 254 graduates, their anticipated lifetime earnings would be in the region of R4 billion at 2015 prices. ${ }^{11}$ In addition to the direct economic benefit to the graduates who are working in the healthcare sector and providing important services to rural communities, there is anecdotal evidence suggesting that the lives of the graduates, and their families, have been impacted in multiple ways, as they engage in meaningful work that is remunerated at a reasonable rate. The 
aim of this study was to better understand the socioeconomic impact on the individuals and their families when rural-origin HCPs work at healthcare facilities in rural areas of KwaZulu-Natal.

\begin{abstract}
Methodology
A cross-sectional mixed methodology was adopted to obtain both quantitative and qualitative data through a questionnaire and from the UYDF database. The quantitative data was collected through a researcher administered questionnaire, which also contained semi-structure questions to obtain qualitative data. The questionnaire contained the following three sections; 1. Demographic characteristics (age, gender, number of siblings, type of school they attended) 2. Employment details (qualification, duration of work, employer, income) 3. Household assets before and after qualifying and starting employment as HCPs. The last section covered the graduate's family of origin as well as their own family, and the type of schools attended by themselves and their children. The UYDF dataset was used to provide background information on all the UYDF graduates who participated in the study.
\end{abstract}

\section{Setting}

The study was conducted in the eight rural district government hospitals in the uMkhanyakude and Zululand Districts in northern KwaZulu-Natal (KZN) province, which is the province most affected by the quadruple burden of diseases (HIV/AIDS and TB, maternal and child mortality, violence and injuries, and non-communicable diseases). The districts are also characterised by a chronic shortage of HCPs in rural public health facilities. ${ }^{12}$

The majority of graduates had attended non-fee-paying, quintile 1 or 2 schools in rural areas, which are generally characterised by poor infrastructure, inadequate human resources and reduced teaching capacity. ${ }^{13}$ Based on the information provided to UYDF when they applied for financial support, the families in which they grew up were poor, with the majority depending on social grants for survival. According to Statistics South Africa, over $76 \%$ of the population living in these districts are unemployed and more than $50 \%$ have not attended school. ${ }^{2}$

The inclusion criteria for this study were all graduates who had been financially supported by UYDF, had returned to serve in their rural district hospital upon completion of their health sciences degrees, and were in at least their second year of work post-graduation or internship. Of the 337 UYDF rural youth who had graduated, 203 were eligible for inclusion in the study.

\section{Sampling strategies}

The 203 UYDF graduates identified for inclusion were employed in 16 district hospitals in rural KZN, with the questionnaires being sent to them via email. However, as only five (5/203) responses were received, a decision was taken to focus on only eight district hospitals, at which nearly $70 \%$ (142) of the 203 eligible graduates worked. The principal researcher, who is a staff member of UYDF, visited these hospitals and, after obtaining informed consent, asked the graduates to complete the questionnaires and answer the qualitative questions. The hospitals were visited on only one occasion, and those graduates who were busy or not available did not participate in the study. All graduates who were available on the day of the interview agreed to participate in the study.

\section{Ethical considerations}

Prior to conducting the study, all necessary ethical requirements were adhered to in accordance with the Nuremberg code. ${ }^{14}$ Ethical approval was granted by the Biomedical Research Ethics Committee of the University of KwaZulu-Natal (BE574/ 17). All the participants read and signed a consent form prior to taking part in the study, and agreed to their responses being recorded on condition that their names were not used in the final report.

We also acknowledge that there might be some bias in the responses in this research study on the basis that the principal researcher was a staff member of UYDF at the time when the study was conducted and graduates' responses could not be verified.

\section{Results}

As at December 2017, there were 337 UYDF graduates, of whom 187 were working in rural healthcare facilities, 11 were specialising, 45 were working in public healthcare facilities and 42 were doing their internship (which cannot be done at a rural district hospital). The rest of the graduates either worked in private practice (27), non-government organisations (NGOs) (8), were studying further (2) or were unemployed (2) (Table 1). Of the 337 UYDF-supported graduates, 145 have completed their workback obligation, of whom 91 continue to work in rural facilities, while an additional 27 are working in public sector healthcare facilities, 15 are in private practice, 4 are specialising and 8 are working for NGOs (Table 1).

Of the 142 eligible graduates at the eight rural hospitals that were included in the study, data were collected from 40 graduates. Although this was less than anticipated, it represents $28 \%$ of the sample and can provide insight into the socioeconomic changes they have experienced since graduating and starting work. Table 2 shows their age, gender, number of siblings, and the type of school that the graduates attended. The mean age of the participants was 31 years, while the genders were equally represented (20 males and 20 females). Most graduates reported having between one and seven siblings for whom they were responsible, while two reported having no siblings. A total of $95 \%(n=35)$ of the participants attended non-fee-paying schools, while $5 \%(n=5)$ attended public fee-paying schools.

Table 3 shows the year in which they completed their university degrees, the number of years they have been employed and their monthly gross salary in South African Rand. All participants completed their degrees between years 2005-2015, had worked for between 2 and 7+ years and earned a gross salary that ranged between R12 000 and R40 000+ per month. Participants represented 12 different health disciplines, most being pharmacists (7), followed by doctors (5), physiotherapists (5), nurses (4) and social workers (4).

To determine whether there had been a change in their household economic and social circumstances, the respondents were asked to indicate their household's assets when they were growing up, and to compare those with their current assets. All participants indicated that they witnessed major changes in their lives as soon as they started working as HCPs (Table 4).

In addition to the changes observed in Table 4, 32 respondents indicated that their parents did not own a car or land, while 8 possessed either of the two. All 40 indicated that 
Table 1: Overview of all UYDF graduates as at December 2017

\begin{tabular}{|c|c|c|}
\hline Location & No. & $\%$ \\
\hline \multicolumn{3}{|c|}{ Work locations of all UYDF graduates in December $2017(n=337)$ : } \\
\hline Internship & 42 & 13 \\
\hline Rural areas & 187 & 56 \\
\hline Public hospitals & 45 & 13 \\
\hline Private hospital & 27 & 8 \\
\hline Specialising & 11 & 3 \\
\hline NGOs & 8 & 2 \\
\hline No post/locum & 8 & 2 \\
\hline Studying & 4 & 1 \\
\hline Unemployed & 2 & 1 \\
\hline Deceased & 3 & 1 \\
\hline Total & 337 & 100 \\
\hline \multicolumn{3}{|c|}{$\begin{array}{l}\text { Work locations of UYDF graduates who had completed their work-bacl } \\
\text { obligations in December } 2017(n=145) \text { : }\end{array}$} \\
\hline Rural areas & 91 & 63 \\
\hline Public hospitals* & 27 & 19 \\
\hline Private hospitals* & 15 & 10 \\
\hline Specialising* & 4 & 3 \\
\hline NGOs & 8 & 6 \\
\hline Total & 145 & 100 \\
\hline \multicolumn{3}{|c|}{ Professional qualifications of UYDF graduates $(n=337)$} \\
\hline \multicolumn{3}{|l|}{ Specialty } \\
\hline Audiologist & 4 & \\
\hline Biomedical technologist & 15 & 4 \\
\hline Clinical associate & 1 & 0 \\
\hline Dentist & 4 & 1 \\
\hline Dental therapist & 10 & 3 \\
\hline Dietitian & 11 & 3 \\
\hline Environmental Health & 1 & 0 \\
\hline Doctor & 113 & 34 \\
\hline Nurse & 40 & 12 \\
\hline Nutritionist & 1 & 0 \\
\hline Occupational therapist & 8 & 2 \\
\hline Optometrist & 14 & 4 \\
\hline Orthotist & 1 & 0 \\
\hline Pharmacist & 31 & 9 \\
\hline Psychologist & 7 & 2 \\
\hline Physiotherapist & 29 & 9 \\
\hline Radiographer & 29 & 9 \\
\hline Social worker & 14 & 4 \\
\hline Speech therapist & 4 & 1 \\
\hline Total & 337 & 100 \\
\hline
\end{tabular}

when they were growing up their parents lived in very poorly built houses, most of which were made of mud. Only four indicated that their parents were involved in informal trading as a type of business for the family's survival. According to the baseline information available in the UYDF database, most of their fathers were absent, either through divorce or being deceased, with most graduates being raised by their mothers and grandparents. From the analysis of the qualitative data, the following five themes were identified: perceived value of education; resources to afford assets; transformed lives; ability to care for siblings and their extended family; and the value attached to having a permanent job and regular income.
Table 2: Participants' demographic characteristics $(n=40)$

\begin{tabular}{lcr}
\hline Characteristic & No. & $\%$ \\
\hline Age (years): & 23 & \\
$\quad$ Youngest & 39 & \\
\hline Oldest & 31 & \\
\hline Mean & & 50 \\
\hline Gender: & 20 & 50 \\
\hline Males & 20 & \\
\hline Females & & 95 \\
\hline Type of school participants attended: & 35 & 5 \\
\hline Non-fee (quintile 1, 2, 3) & 5 & 5 \\
\hline Public fee-paying schools & & 31 \\
\hline Number of siblings: & 2 & 51 \\
\hline 0 & 12 & 14 \\
\hline 1-3 & 20 & 59 \\
\hline 4-6 & 6 & 42 \\
\hline 7+ & 24 & \\
\hline Marital status: & 16 & \\
\hline Married & & \\
\hline Unmarried & & \\
\hline
\end{tabular}

\section{Graduates' perceived value of education}

Participants acknowledged the value that their education had played in their lives, with most being the first graduates in their families, with obtaining a university degree having given them status and prestige in their family and community:

'Without graduating from university, I would not have had this job. This degree has changed my personality and the ways in which I was viewed by the community members before my studies.' (Occupational therapist)

The hospitals and the community have become the beneficiaries of the value embedded in the education of these rural-origin graduates. As one HCP reported:

II now have value in my family and in the community ever since I graduated from the university. Working as a radiographer at my local hospital and being the first graduate in my entire family are both of great value.' (Radiographer)

\section{Resources to afford assets}

In clarifying the quantitative data on the changes in their material assets, they indicated that:

'The house I grew up in did not have electricity or running water. Also, in my entire family, no one had ever owned a car but I have one and I have built myself a house and one for my parents.' (Medical doctor)

A key achievement was their improved financial status, which enabled them to build houses and purchase a car to travel to work. A similar response was given by an HCP when asked about things that she can now afford that she could not have afforded previously:

'I have been working for the past five years now. I have built a house and it is fully furnished. I drive my own car although I am still paying for it but this year I will settle its balance and become debt-free.' (Pharmacist) 
Table 3: Professional characteristics of participants $(n=40)$

\begin{tabular}{|c|c|c|c|c|c|}
\hline Characteristic & No. & $\%$ & Profession & Male, no. & Female, no. \\
\hline Study completion year: & & & Audiology & 1 & 1 \\
\hline 2005-2011 & 9 & 23.8 & Dentistry & 2 & 0 \\
\hline 2014-2015 & 16 & 41.2 & Medicine & 3 & 2 \\
\hline Number of years in employment: & & & Nursing & 1 & 3 \\
\hline $2-3$ years & 14 & 35.0 & Occupational therapy & 1 & 2 \\
\hline $4-6$ years & 17 & 42.5 & Optometry & 1 & 1 \\
\hline $7+$ years & 9 & 22.5 & Pharmacy & 3 & 4 \\
\hline Current gross monthly salary: & & & Physiotherapy & 3 & 2 \\
\hline R10000-R24999 & 17 & 42.5 & Radiography & 1 & 1 \\
\hline R25000-R30000 & 11 & 27.5 & Radiology & 1 & 0 \\
\hline R35000-R40000+ & 12 & 30.0 & Social work & 1 & 3 \\
\hline
\end{tabular}

Graduates indicated that regular income was key to their ability to afford assets.

\section{Transformed lives}

All respondents referred to their lives as being transformed from their past to present with participants reporting that they had observed changes in almost every aspect of their lives. In addition to being able to afford assets, many other things had changed in their lives:

I am now able to afford $80 \%$ of what was a dream to me. My children are going to a private school. I am thankful to the UYDF to having enabled us to get where we are today.' (Dentist)

They highlighted how their dreams had been realised, and that they felt empowered by the opportunities provided by the scholarship scheme. A similar quote was provided by another $\mathrm{HCP}$ indicating that:

II met my current wife in the Umthombo cohort and we are now married with children. I also own a business in our local area which is an additional source of income for me.' (Physiotherapist)

Similar sentiments were shared by another graduate, who explained how her life had been transformed upon taking up her full-time professional job:

'The opportunity from UYDF has transformed my life and that of my family and community at large. I now feel the sense of belonging and found my place in middle-class society. My transformation is being used to transform also the health system at our hospital.' (Dietitian)

Table 4: Household socioeconomic assets before and while working after graduation

\begin{tabular}{|c|c|c|c|c|}
\hline Factor & Household socioeconomic assets & Previously owned (\%) & Currently owned (\%) & Observations \\
\hline & Alternative power source & 05.3 & 12.5 & Doubled \\
\hline \multirow[t]{5}{*}{ Power supply } & Electricity & 41.0 & 92.5 & Doubled \\
\hline & Power generator & 10.3 & 20.6 & Doubled \\
\hline & Solar energy & 13.2 & 00.0 & Decreased \\
\hline & Computer or laptop & 10.3 & 74.4 & Increased $7 x$ \\
\hline & DVD player & 35.9 & 48.7 & Increased \\
\hline \multirow[t]{12}{*}{ Equipment } & Electric or gas stove & 56.4 & 92.1 & Doubled \\
\hline & Internet by computer & 05.1 & 29.7 & Increased $6 x$ \\
\hline & Internet by mobile & 12.8 & 79.5 & Increased $6 x$ \\
\hline & Microwave & 25.6 & 87.5 & Tripled \\
\hline & Mobile phone & 69.2 & 92.3 & High increase \\
\hline & Radio & 94.9 & 74.4 & Use decreased \\
\hline & Refrigerator & 48.7 & 95.0 & Doubled \\
\hline & Satellite TV or DSTV & 18.0 & 79.5 & Quadrupled \\
\hline & Sewing machine & 18.0 & 02.9 & Decreased \\
\hline & Television & 43.6 & 85.0 & Doubled \\
\hline & Telephone & 20.5 & 35.9 & Increased \\
\hline & Washing machine & 05.1 & 21.1 & Quadrupled \\
\hline Ablution & Toilet facility indoors & 15.4 & 71.1 & Increased $5 x$ \\
\hline \multirow[t]{3}{*}{ Transport } & Bicycle & 30.8 & 08.8 & Decreased \\
\hline & Motorcycle & 00.0 & 00.0 & None \\
\hline & Motor vehicle & 23.1 & 82.5 & Quadrupled \\
\hline
\end{tabular}




\section{Ability to care for siblings and extended family}

Caring for siblings is part of life for most rural families, with the participants indicating that as soon as they started to earn an income, they were expected to become the supporter of the entire family, anecdotally referred to as 'black tax'. The participants reported that they were able to provide financial support to their families, which they could not have afforded without becoming an HCP and obtaining employment:

'In my second year of my work, I purchased a car and started to build a house for my family. Both mom and my three siblings are now staying in a nice house. I am paying for my siblings' school fees and we can now afford all basics without trouble.' (Social worker)

\section{Value of permanent job and regular income for graduates}

Their achievements were attributed to the value of having a permanent job, which assures them of a sustainable income. Most indicated that, without a permanent job, much of what they have realised would have not been achieved, as job security is required to get a bank loan for a house or car:

'I feel that I am privileged to complete my degree and get a permanent job automatically. Most of my friends from university are still struggling to get a placement. The UYDF has made it easy for us. Having a permanent job is a big assurance that there is a month-to-month income and this allows me to budget very well and spend wisely.' (Medical doctor)

The transformation in their lives was described using terms such as: 'abilities to provide for my family', 'having a regular source of income' and 'permanent position in the hospital'.

\section{Discussion}

The aim of this study was to understand the social and economic impact on the individual and family when rural-origin graduates returned to work as HCPs. Given the context of large-scale unemployment in South Africa, specifically among the youth, the UYDF provides training for employment in the healthcare sector and ensures that graduates have access to jobs in the public sector on completion of their qualifications. Although not guaranteed, the vast majority of UYDF graduates have been able to find employment upon graduation because of their professional qualification and understanding of the local language and culture.

The UYDF supports the government's priority focus on addressing unemployment by training youth for jobs in the health sector. Reports from the Department of Higher Education and Training (DHET) and Statistics SA (StatsSA) suggest that, in 2017, a total of 7.8 million youth were neither in education, employment nor training (NEET). ${ }^{16,2}$ The NEET rate for this age group increased from $38.2 \%$ in 2013 to $38.6 \%$ in $2017 .{ }^{16}$ Rural youth are the worst affected by unemployment due to poor secondary schooling, lack of information concerning opportunities and absence of financial support from their families. The UYDF support addresses all these with its focus on rural youth, and supports them by providing training to fill posts in the healthcare sector.

\section{Alignment of the UYDF initiative with SA-NDP}

The main purpose of the NDP is to eradicate poverty and reduce inequality in South Africa by $2030 .^{1}$ In terms of inequality, the
2017/2018 report by the South African Human Rights Commission (SAHRC) indicated that SA remains the most unequal country in the world, with $64 \%$ of Black South Africans, $41 \%$ of Coloured citizens, $6 \%$ of Indian citizens and only $1 \%$ of White citizens living in poverty. ${ }^{17}$ This inequality is driven by limited education attainment leading to unemployment and poverty, in which many rural communities are trapped. ${ }^{2}$ Since 1999, the UYDF has been identifying youth from rural areas and supporting them at universities where they qualify to become $\mathrm{HCPs}$, on the understanding that they will return there to serve where the demand for healthcare services is high. With an annual pass rate of $92 \%$ over the past six years, the UYDF has shown that, with focused support, rural youth can train and qualify as HCPs. ${ }^{10}$ The UYDF model aligns not only with the NDP 2030 plan, but also with the South African 10-point plan to improve the health system.

The findings in this research were consistent with the literature on the role of education in socioeconomic transformation, and highlights the part that education and employment can play in Third World countries. Cloete (2015) conducted a study on youth unemployment in SA, and concluded that those who find jobs reported a feeling of restored dignity, while those who remain unemployed felt undeserving and without a place in society. ${ }^{18}$ In line with the finding of this study, the graduates who participated reported being role models in their communities, as they built houses for their parents and became involved in economic activities, which, in addition to their income tax, contributes to rural economic development.

\section{Education leading to employment}

All of the graduates were aware of how different their lives would have been had they not graduated as an HCP and secured a permanent well-paying job in the healthcare sector. The benefits reported by graduates in this study were only possible because their education led to employment, that is, they had studied a scarce skill where numerous posts were available in rural hospitals (due to financial constraints within the Department of Health this may no longer be the case). Post-school education alone may not lead to employment, as many graduates in South Africa remain unemployed. ${ }^{2}$ Thus, the findings in this study are consistent with previous publications on the role of education as being key to employment. A study of youth in India confirms the link between education and employment as key to eradicating unemployment and poverty in this population. ${ }^{19}$ Other studies conducted in the United States revealed similar results, and support the claim that education for employment is an investment for the government, ${ }^{20}$ while others suggest that it contributes to the creation of permanent jobs for the youth. ${ }^{21}$ In addition, a study by Brock (2010) highlights that educating adults does break barriers and often contributes to them accessing economic opportunities. ${ }^{22}$

\section{The UYDF model as a response to national priorities}

The youth unemployment rate in SA is alarming, ${ }^{2}$ and has become a national key priority that must be addressed. Initiatives that respond to the national priority of youth employment are thus needed, and should be supported by the national government. Evidence from national and international studies has shown that rural youth can succeed at university despite coming from poorly resourced as well as rurally based schools, ${ }^{23-27}$ can successfully qualify as $\mathrm{HCPs}^{25,10}$ and can be part of the solution to unemployment in SA. 


\section{Limitations}

This research study had some limitations. The self-reported data could not be verified, and the potential response bias due to the affiliation of the principal researcher to the UYDF may have influenced the results. The issue of social desirability bias was also a limitation to the study. Finally, the sample size was relatively small: 40 of 142 eligible graduates participated in the study.

\section{Conclusion}

All graduates who participated in the study reported improved socioeconomic status in their own lives and that of their families as a result of being employed as an HCP. The graduates saw the value of education, as they reported investing in better education for their siblings and own children. Training rural youth for employment in scarce skills (such as health) is key to improving their socioeconomic lives, as well as that of their families and the organisations for which they work. The value of education must not be ignored in the fight against youth unemployment in SA. Findings from this study showed how the socioeconomic impact made by having a permanent well-paying job transformed the lives of those young people supported by the UYDF, helped restore their dignity and self-respect, and made them proud of their contribution to their families, and to healthcare services at the local hospital.

Disclosure statement - No potential conflict of interest was reported by the authors.

\section{ORCID}

Richard Gavin McGregor (D) http://orcid.org/0000-0002-43087818

Ganzamungu Zihindula (1D) http://orcid.org/0000-0002-9865-4672

\section{References}

1. South African Government. National development plan 2030. Republic of South Africa; 2017. [cited 2019 Mar 2019]. Available from: www.gov.za

2. Statistics South Africa. Quarterly labour force survey; 2018. [cited 2019 Mar 11]. Available from: http://www.statssa.gov.za/? $p=10658$

3. David A, Guilbert N, Hamaguchi N, et al. Spatial poverty and inequality in South Africa: a municipality level analysis. Cape Town: SALDRU, UCT; 2018. SALDRU Working Paper Number 221.

4. Kruss G, McGrath S, Petersen I, et al. Higher education and economic development: the importance of building technological capabilities. Int J Educ Dev. 2015;43:22-31.

5. Glewwe $P$, Maïga $E$, Zheng $H$. The contribution of education to economic growth: a review of the evidence, with special attention and an application to sub-Saharan Africa. World Dev. 2014;59:379-393.

6. Efanga IS, Oleforo AN. Economic impact of tertiary education on manpower resource development in Nigeria. Int J Acad Res. 2012;4 (3):105-108

7. Harbison FH. Human resources as the wealth of the nations. New York: Oxford University Press; 1973.

8. Olaniyan DA, Okemakinde T. Human capital theory: implications for educational development. Eur J Sci Res. 2008;24(2):157-162.
9. Mitra D. Pennsylvania's Best investment: the social and economic benefits of public education. Pennsylvania State University. Available from: https://www.elc-pa.org/wp-content/uploads/2011/ 06/Bestlnvestment_Full_Report_6.27.11.pdf on16 May 2019

10. MacGregor RG, Ross AJ, Zihindula G. A rural scholarship model addressing the shortages of healthcare workers in rural areas. S Afr Health Rev., Health Sys Trust. 2018: 49-55.

11. MacGregor RG, Zihindula G, Chola L, et al. Health education: an expense or an investment. S Afr Med J. 2019. In Press

12. Department of Health. 2017/2018 Annual Report Vote7. KwaZulu-Natal Provincial Department of Health; 2018. [cited 2019 Mar 11].

13. Mtubatuba Municipality. Mtubatuba Local Municipality Final IDP 2017/2018-2022. [cited 2019 Mar 11]. Available from: http:// mtubatuba.org.za/wp-content/uploads/2017/07/MTUBATUBA-LMFINAL-IDP-2017-18-DATE-27-JUNE-2017-latest-V3.pdf

14. Roets L. Protection of human research participants: a structured review. S Afr Med J. 2017;107(10):847. DOI:10.7196/samj.2017. v107i10.1253. [cited 2019 Mar 11].

15. MacGregor RG. Umthombo Youth Development Foundation Annual Report 2017. [Internet]. [cited 2019 Mar 11]. Available from: https:// www.umthomboyouth.org.za.

16. DHET. Department of higher education and training 2017/2018 report. 2017 South Africa Government. [cited 2019 Mar 11]. Available from: https://www.gov.za/documents/department-highereducation-and-training-annual-report-20172018-9-sep-2018-0000.

17. Modise K. South Africa is most unequal country in the world. South Africa's Human Rights Commission; 2018. [cited 2019 Mar 11]. Available from: www.ewn.co.za/2018/o7/12/sahrc-sa-is-most-unequ al-country-in-world

18. Cloete A. Youth unemployment in South Africa: a theological reflection through the lens of human dignity. Missionalia. 2015;43(3):513525.

19. Raghbendra JHA. Education and employment: the big push needed for India's youth. The World Bank; 2015; [cited 2019 Mar 11]. Available from: www.worldbank.org

20. Belfield $\mathrm{C}$, Levin $\mathrm{H}$. The economics of investing in opportunity youth. New York: Civic Enterprises; 2012; [cited 2019 Mar 11].

21. Ball L, DeLong B, Summers L. Fiscal policy and full employment. Washington (DC): Center on Budget and Policy Priorities; 2014 [cited 2019 Mar 11].

22. Brock T. Young adults and higher education: barriers and breakthroughs to success. Future Child J. 2010;20(1):109-132.

23. Milner HR, Cunningham HB, Murray I, et al. Supporting students living below the poverty line. Nat Youth Risk J. 2017;2(4):1-20.

24. Purohit B, Bandyopadhyay T. Beyond job security and money: driving factors of motivation for government doctors in India. Hum Resour Health. 2014;12:12. DOI:10.1186/1478-4491-12-12.

25. Ross AJ. Working in rural areas- the experiences of Umthombo youth development foundation graduates. Afr J Prm Health Care Fam Med. 2014;6(1):673-677.

26. Rourke J, Dewar D, Harris K, et al. Strategies to increase the enrollment of students of rural origin in medical school: Recommendations from the society of rural physicians of Canada. CMAJ. 2005;172(1):62-65. DOI:10.1503/cmaj.1040879.

27. Tumbo JM, Couper ID, Hugo JF. Rural-origin health science students at South African universities. S Afr Med J. 2009;99(1):54-56. 